\title{
14
}

\section{Two Approaches to Case-Based Teaching in Science: Tales From Two Professors}

\author{
Colin Montpetit \\ University of Ottawa \\ Lovaye Kajiura \\ McMaster University
}

Case-based teaching and learning strategies can offer instructors effective pedagogical tools to scaffold student learning through activities designed to fulfill teaching objectives and desired student learning outcomes. In science disciplines, programs strive to impart knowledge in addition to providing students environments through which they can learn through collaboration. Case-based studies can effectively expose students to the process of science and encourage them to work through facts, analyze data, formulate solutions, draw conclusions, and predict consequences. Despite the versatility of case studies as teaching and learning tools, many factors influence their implementation in a given teaching environment. Inasmuch, the manner in which they are used is typically dependent upon specific teaching and learning objectives and the historical context of the course (e.g., student enrolment, year of instruction, lecture vs. lab vs. tutorial settings). In this article, we discuss two novel approaches for case-based teaching and learning in Biology as a means to convey lecture content, encourage students to apply fundamental concepts taught in lectures, while exposing them to the process of science in a dynamic environment.

\section{Introduction}

C ase studies are stories with educational messages and are quite useful in the context of helping professors achieve teaching and learning objectives in the classroom (Dunne \& Brooks, 2004; Handelsman et al., 2004; Herreid, 2006a,b). Despite the versatility of case studies as pedagogical tools to target learning outcomes and develop specific behaviours, their implementation may present several challenges with the commitment of time needed to design and develop the cases and compile their supplementary 
resources (Herreid, 2001, 2004, 2006a,b; Yadav et al., 2007). It may also take time for students to become accustomed to the case-based study approach. A number of factors can influence the decision making process on how best to incorporate case based teaching and learning strategies in the classroom (Dunne \& Brooks, 2004; Cameron, 1999; Gedalof, 1998; Guo \& Jamal, 2007). Identifying these factors is an important first step in achieving success using case studies as a teaching and learning tool in your classroom. Science education in higher learning typically strives to impart a vast amount of factual information in addition to providing students opportunities and environments to learn through collaboration and scientific inquiry. While we both agree that case studies provides us opportunities to promote interdisciplinary learning and to reveal integrated linkages in course content, our approaches to using case-based teaching are quite different and dictated by our local realities. For example, program goals, class size, course teaching objectives and student learning outcomes, enrolment, and the make-up of the student population in the class are factors that have and continue to influence our approaches to case-based teaching. In each of our academic settings, case studies are used as pedagogical tools to convey subject matter and encourage collaborative learning while scaffolding the process of science. During this process, students may work through facts, analyze date, formulate solutions, draw conclusions, and predict consequences. The manner in which this can be achieved can be accomplished in many different fashions. Currently, journal articles, websites, and texts provide a wealth of information regarding teaching and learning with case studies. In this article, we share our two approaches to case-based teaching. Our stories and insights will hopefully provide ideas to new and old users of case-based teaching and learning in science.

\section{Approach A}

Case-based teaching and learning was incorporated into my second year large enrolment Genetics course ( -600 students) to address undergraduate degree level expectations, results of concept assessment tests (Smith et al., 2008), and student evaluations. Overall my objectives for using case studies as a teaching and learning tool were to explore the unifying themes and research methodologies in biology and to use them as a vehicle to provide students opportunities to engage in scientific inquiry through critical thinking and collaborative learning. Despite the communicated benefits of case-based teaching and best practices for introducing case-based teaching in the classroom (Dunne \& Brooks, 2004; Herreid, 2006a,b), early attempts at introducing case-based teaching in my large enrolment course have been met by a number of challenges. The most notable perceived risk is lack of substantive coverage of the course content followed by student resistance and their ineffectiveness of increasing conceptual understanding of genetic concepts in such an environment. The extent to which the benefits of case-based teaching can be obtained with large undergraduate classes is not as evident (Herreid, 2006a,b). To achieve a satisfactory reconciliation, I describe here an ongoing initiative to develop a case-based teaching and learning strategy using scientific articles in the field of genetics to frame conceptual understanding of concepts in genetics. In this second year large enrolment introduction to genetics course, preselected published scientific articles are currently used as trigger case studies (Herreid, 2006a,b) to lead students through a series of interactive lectures that progressively reveal the nature of scientific investigations in the field of genetics (Ebert-May \& Hodder, 2008). Following traditional approaches to study the functions of genes (e.g., forward genetics and reverse genetics analysis), sections of the published articles are progressively released throughout learning units (e.g. interrupted case study approach) (Herreid, 2006a,b) to specifically focus on the knowledge and conceptual understanding needed to effectively explore the experimental design and the conclusions of investigations. Alongside pre-lecture quizzes, think-pair-share activities, and professor led-lectures, scientific articles as case studies provide a framework through which course activities are structured to scaffold the conceptual understanding relevant for scientific analysis in the field (Ebert-May \& Hodder, 2008). 


\section{Scientific article in the field of genetics as a case study}

A common experimental approach to study the function of genes is Forward Genetics analysis. Through this approach, variants (mutants) for a given biological phenomena are obtained and used to investigate genetic linkages to the phenomena. Using genetic screening methodologies, genetic variants of interest are identified and used in mating experiments to confirm the genetic basis of the phenomena, to map the chromosomal location of the gene, and to determine the DNA sequence of the gene (Griffiths et al., 2012). Thus using methodologies that permit the analysis of the transmission of genes and genomes from one generation to the next in this context, investigators are able to confirm and infer on thegenetic basis of various biological phenomena. Inasmuch, published articles in genetics provides convenient pedagogical tools to design interrupted cases enabling students and instructors to progressively explore and discuss the topics directly linked to the knowledge and understanding needed to appropriately design experiments to investigate the genetic basis of traits and the conceptual understanding to analyse and interpret data. An example of this approach is illustrated within the context of forward genetics analysis to discover the function of genes involved in recessive deafness. The paper "A Forward Genetics Screen in Mice Identifies Recessive Deafness Traits and Reveals That Pejvakin is Essential for Outer Hair Function," published in the Journal of Neuroscience, provides a detailed account of the experimental procedures that were followed to identify mutations involved in hearing loss (Schwander et al., 2007). The progressive exploration of this paper allows students to explore the concepts and knowledge used to design the investigation to specifically identify DNA mutations involved in the loss of hearing. In this context, students are led through the exploration of DNA mutations, genetic inheritance of traits, and the methodologies and analytical procedures that permitted the investigators to detect mutations, study patterns of inheritance through the analysis of phenotypic ratios of crosses (e.g., matings) and pedigree analysis, and the analysis of DNA sequences.
Several topics within the course have been addressed through this case-based teaching approach. Early results from course assessments (concept assessment tests and student satisfaction surveys) communicate higher learning gains in the conceptual understanding of genetic concepts, student satisfaction regarding the relevance of the course, and overall course ratings. In future versions of the course, we will explore the role of student response systems in enhancing case-based teaching and learning.

\section{Approach B}

How can lectures be designed to be more engaging for students? One of the intrinsic motivators for student performance suggests that the lecture topics should have personal relevance and significance to the lives of students in order to engage their interest (Mustoe \& Croft, 1999; Raju \& Sanker, 1999). Feedback from student surveys suggests that casebased lecture activities may be helpful in linking concepts taught in lectures with real world examples. Given that cancer may impact students at multiple levels: either individually, or family members, and friends, it represents a topic of broad personal and global relevance.

At McMaster University, three Level 1 undergraduate Biology courses (Introductory Biology - Biology 1P03, Cellular \& Molecular Biology - Biology 1A03, and Biodiversity, Evolution, \& Humanity - Biology 1M03) utilize the integrated case-based studies approach within the teaching, learning, and research realms. Bloom's cognitive levels are easily implemented when utilizing the case based study approach (Anderson \& Krathwohl, 2001; Grant, 1997; Manning, 1997). Case-based studies may encourage students to acquire the fundamental knowledge of the concepts, definitions, and principles related to a keystone topic, such as the field of cancer. Students progressively learn to explain and interpret the meaning of the results of research as evident in the primary scientific literature. Applications and analyses of scientific references facilitate the students to employ the 
principles and concepts to solve a proposed problem, such as answering the question: "Is it possible to find a single cure for all cancers?" While exploring interactively, this approach reinforces the student's recognition of the interrelationships (or integrated linkages) between other fields of study. Synthesis of proposed cures for cancer also facilitates creativity as the student's research team propose "cures" that are novel or what they believe is original from their knowledge. Finally, case-based studies lead students to evaluate the aforementioned by formulating judgments, based upon their critical thinking skills, of pre-established criteria. This approach may assist with other learning scenarios, such as problembased learning (Woods, 1994).

Using an integrated and investigative case-based study approach, Biology students progressively examine different levels of cancer: molecular, cellular, evolution, genetic, ecological, and global (Kajiura, 2010). An integrated approach to studying cancer reveals the scaffolding linkages between various fields of study. Students consult the primary scientific literature to acquire knowledge of cancer. In their research teams, they shared their information and critically appraised each other's cures for cancer. This approach was very helpful, since after the course had finished students continued to correspond with one another on online discussion forums updating their colleagues regarding their most recent proposed cures based on current research findings.

The suggested format for presenting the case-based study includes: 1) presenting the students with the case-based study description: introducing the topic provides the framework and context of the case that the students are to consider, 2) delivering the questions that the students are to consider will stimulate further questions for the students to investigate. These questions are a beneficial feature of case-based studies since they encourage students to be analytical and creative in generating questions for further investigation, 3) presenting interesting supplementary web links, videos, and guest speakers to give the students an appreciation of the complexity and the breadth of knowledge needed to be considered when researching a topic and formulating a possible solution, 4) documenting professor and student perspectives throughout the process of case-based study analyses. Recording of topics in journals or blogs, stimulated further questions to investigate, provided feedback regarding the ease or challenges of the process, and facilitated interpersonal collaboration perspectives, 5) encouraging the synthesis of ideas and collegiality/ teamwork by facilitating critical thinking skills in the students, when they present their answers and solutions (this is research realistic and will prepare them with important transferable skills related to effective diplomatic communication skills), and 6) professors and students may summarize their key points during closure of the case-based study, or they may leave the case study open so that they facilitate life-long learning and interest in future research developments.

Classroom response systems (clickers) provide students with an opportunity to express and demonstrate their knowledge. This provides students and their professors with immediate feedback so that clarification and elaboration may be delivered regarding a specific concept or topic (Duncan, 2005; Herreid, 2006a,b). Formative and summative assessments may be implemented throughout the course. Classroom response systems may be utilized during pre-lectures, in lectures, and post-lectures. Overall course evaluations and student surveys provided feedback regarding their perspectives on the case studies. Concept inventories of core topics may also be used to gauge the level of learning and progress.

\section{Conclusion}

The aforementioned descriptions reveal factors that have influenced our approaches to integrate casebased teaching and learning in our science courses. These approaches may be customized to fit diverse lecture, tutorial, laboratory settings. As educators, case-based studies provide opportunities to expose students to the process of scientific reasoning. Currently, ongoing studies are evaluating the impact of these approaches on learning gains. 


\section{References}

Anderson, L.W. \& Krathwohl, D.R. (Eds.). (2001). A taxonomy for learning, teaching and assessing: $A$ revision of Bloom's Taxonomy of educational objectives. New York: Longman.

Cameron, B. (1999). Active learning (Green Guide No. 2). Halifax, NS: Society for Teaching and Learning in Higher Education.

Duncan, D. (2005). Clickers in the classroom: How to enhance science teaching using classroom response systems. San Francisco: Pearson Education and Benjamin Cummings.

Dunne, D. \& Brooks, K. (2004). Teaching with cases (Green Guide No. 5). Halifax, NS: Society for Teaching and Learning in Higher Education.

Ebert-May, D. \& Hodder, J. (2008). Pathways to scientific teaching. Sunderland, Massachusetts: Sinauer Associates, Inc. Publishers.

Handelsman, J., Ebert-May, D., Beichner, R., Bruns, P., Chang, A., DeHaan, R., Gentile, J., Lauffer, S., Stewart, J., Tilghman, S.M., \& Wood, W. (2004). Scientific teaching. Science, 304(5670), 521-522.

Herreid, C.F. (2001). The case study: Don't! What not to do in teaching cases. Journal of College Science Teaching, 30(5), 292-294.

Herreid, C. F. (2004). Why a case-based course failed: An analysis of an ill-fated experiment. Journal of College Science Teaching, 33(3), 8-11.

Herreid, C.F. (Ed.). (2006a). Start with a story: The case study method of teaching college science. Arlington, VA: National Science Teachers Association.

Herreid, C.F. (2006b). Clicker cases. Journal of College Science Teaching, 36(2), 43-47.
Gedalof, A. (1998). Teaching large classes (Green Guide No. 1). Halifax, NS: Society for Teaching and Learning in Higher Education.

Grant, R. (1997). A claim for the case method in the teaching of geography. Journal of Geography in Higher Education, 27(2), 171-185.

Griffiths, A.J.F, Wessler, S.R., Carroll, S.B., \& Doebley, J. (2012). Introduction to genetic analysis (10th ed.). New York: W.H. Freeman and Company.

Guo, S., \& Jamal, Z. (2007). Cultural diversity and inclusive teaching (Green Guide No. 8). London, ON: Society for Teaching and Learning in Higher Education.

Kajiura, L. (2010). Exploring cancer: An integrated approach to discovering cures- case study \& teaching notes. In Biology on the cutting edge concepts, issues, and Canadian research around the globe. Toronto: Pearson Education.

Manning, B. (1997, October). The cases for cases. Professional and Organizational Network in Higher Education Annual Conference, Haines City, Florida.

Mustoe, L.R. \& Croft, A.C. (1999). Motivating engineering students by using modern case studies. European Journal of Engineering Education, 15(6), 469-476.

Raju, P.K. \& Sanker, C.S. (1999). Teaching realworld issues through case studies. Journal of Engineering Education, 88(4), 501-508.

Schwander, M., Sczaniecka, A, Grillet, N., Bailey, J.S., Avenarius, M., Najmabadi, H., Steffy, B.M., Federe, G.C., Lagler, E.A., Banan, R., Hice, R., Grabowski-Boase, L., Keithley, E.M., Ryan, A.F., Housley, G.D., Wiltshire, T., Smith, R.J.H., Tarantino, L.M., \& Muller, U. (2007). A forward genetics screen in mice identifies recessive deafness traits and 
reveals that Pejvakin is essential for outer hair cell function. Journal of Neuroscience, 27(9), 2163-2175.

Smith, M.K., Wood, W.B., and Knight, J.K. (2008). The Genetics Concept Assessment: A New Concept Inventory for Gauging Student Understanding of Genetics. CBE - Life Sciences Education, 7, 422-430.

Woods, D. R. (1994). Problem-based learning: How to gain the most from PBL. Hamilton, Ontario, Canada: Donald R. Woods Publisher.

Yadav, A., Lundeberg, M., DeSchryver, M., Dirkin, K., Schiller, N., Maier, K., \& Herreid, C.F. (2007). Teaching science with case studies: A national survey of faculty perceptions of the benefits and challenges of using case studies. Journal of College Science Teaching, 37(1), 34-38.

\section{Biographies}

Lovaye Kajiura is an Assistant Professor of Biology at McMaster University. Her pedagogical research interests focus upon integrated case-based studies, linkages between technology and learning, and collaborative mentorship at diverse levels of education.

Colin Montpetit is a Science Lecturer in the Department of Biology at the University of Ottawa. His work focuses primarily on how to help students learn biology and teachers adopt educational practices in their classroom. Specifically, he is interested in investigating learning and teaching strategies using case studies.

Lovaye and Colin are founding members of the Ontario Consortium of Undergraduate Biology Educators (oCUBE) and the Canadian Consortium of Excellence in University Biology (CCEUB). 